\title{
On meeting collective needs of the local community - selected issues ${ }^{1}$
}

\begin{abstract}
Monika Augustyniak*
Summary: The subject of this article is the analysis of one of own tasks, which aims to satisfy the needs of the local community by supporting and disseminating the self-government idea, including creating conditions for the operation and development of auxiliary units and implementation of programmes to stimulate civic activity. The subject matter has been presented on the basis of obligatory, quasi-obligatory and optional forms of satisfying collective needs of the community in the light of article 7 par. 1 point 17 of the Act on municipal self-government together with an indication of the role and significance of municipal bodies in the organizational and functional structure of the mechanisms presented, with the help of which the municipality's own task is implemented. Discussing this task is important due to the fact that it is a form of implementation of the principle of subsidiarity and deconcentration in the self-government community.
\end{abstract}

Keywords: social participation, obligatory and optional forms of satisfying collective needs of the local community by supporting and disseminating the self-government idea, subsidiarity and deconcentration.

\section{Introduction}

According to article 166 par. 1 of the Constitution of the Republic of Poland the subject of own tasks of the municipality is to meet the needs of the self-government community. This means that it is acceptable to meet the individual needs of residents, which are of public nature. Individual needs articulated by residents which do not have such a nature do not fall within the scope of that concept [see Stasikowski 2005, p. 136]. In article 7 of the Act of 8 March 1990 on municipal self-government ${ }^{2}$ the legislator pointed out that satisfying the collective needs of the local community is the basic own task of the

Research project carried out at the Faculty of Law, Administration and International Relations at Andrzej Frycz Modrzewski Krakow University financed from funds for statutory activities on the basis of the decision no. WPAiSM/ DS/4/2016-KON.

2 See the Act of 8 March 1990 on municipal self-government (consolidated text Journal of Laws of 2017 item 1875 as amended) - hereinafter referred to as AMSG. municipality ${ }^{3}$. In addition, the legislator introduced in this article an additional criterion in the form of 'collective' needs of the community, which means meeting needs that arise by summing up individual needs of people

\footnotetext{
M. Stahl emphasizes that the municipality carries out its own task in substitution for the state, on its own behalf. These are tasks given to it because of their locality and connection with meeting the needs of the community [see Duniewska et al., 2004, p. 343]. See also judgement of the Appeal Court in Kraków of 12 April 2016 (I ACa 1827/15, LEX no. 2052605): "Article 166 par. 2 of the Constitution of the Republic of Poland shows that in relation to commissioned tasks the role of local bodies in essence comes down to executive functions, not creative ones, because the act defines the manner of their execution. The legislator commissioning to the self-government unit tasks other than its own is obliged to specify their scope in detail and provide financial resources that fully cover their performance."
}

\section{* Monika Augustyniak}

Faculty of Law, Administration and International Relations

Andrzej Frycz Modrzewski Krakow University ul. Gustawa Herlinga-Grudzińskiego 1, 30-705 Kraków e-mail: monikaaugustyniak1@gmail.com 
living in a given area [see Dolnicki, 2000, p. 163 et seq.]. Whereas the term 'satisfying' should be understood as "all legal forms that the municipality can use and which have been granted to it by law in order to carry out tasks." [Moll T., 2016, p. 215].

The subject of this article is the analysis of one of the tasks included in the catalogue in article 7 of AMSG, which aims to satisfy the needs of the local community 4 "by supporting and disseminating the self-government idea, including creating conditions for the operation and development of auxiliary units and implementation of programmes to stimulate civic activity ${ }^{5}$." The subject matter will be presented on the basis of selected obligatory, quasi-obligatory and optional forms of satisfying collective needs of the community in the light of article 7 par. 1 point 17 of AMSG together with an indication of the role and significance of municipal bodies in the organizational and functional structure of the mechanisms presented. Discussing this task is important due to the fact that it is a form of implementation of the principle of subsidiarity ${ }^{6}$ and deconcentration ${ }^{7}$ in the self-government community.

\footnotetext{
M. Szydło argues that "the basic public aim (interest) (public value) which territorial self-government units are obliged to fulfil due to their public duties is (...) satisfying the needs of the society (community), and specifically satisfying the needs articulated by society as a whole, by various social groups and by individual members of that society" [see Szydło, 2008, p. 42].

See article 7 par. 1 point 17 of AMSG. See also: [Wacinkiewicz, 2016, p. 247].

6 A. Wiktorowska indicates that the principle of subsidiarity declares the division of tasks and competences between a smaller community and a larger community. Whereas, if the smaller community is able - also with the help of the larger community - to perform certain tasks, they should no longer be carried out by the larger community. The larger community should only undertake tasks which the smaller community can not undertake alone; however, there is no substantive criterion that would allow to determine when the possibilities of the smaller community are exhausted and who would decide if and when such a situation arises [Wiktorowska, 2013, p. 220].
}

There is a fundamental difference between the concepts of decentralization and deconcentration, which consists in

\section{Satisfying collective needs of the community by supporting and disseminating the idea of self- government in the municipality - obligatory and quasi-obligatory forms}

The catalogue of own tasks in the field of supporting and disseminating the idea of self-government includes normative instruments provided for by obligatory or quasiobligatory legal provisions. These include: Warsaw neighbourhoods and a strengthened instrument of residents' resolution initiative called the civic initiative and the civic budget. The last two elements belong to the category of quasi-obligatory mechanisms, because the legislator in the Act of 11 January 2018 on amending certain acts to increase the participation of citizens in the process of electing, operating and controlling certain public bodies ${ }^{8}$ provided for a legal framework for their operation at the level of the Act on municipal self-government, making them to a certain extent obligatory mechanisms.

Warsaw neighbourhoods are one of the types of auxiliary units of the municipality. As the only ones in the Polish legal order, they are obligatory ${ }^{9}$. Due to their structure and scope of competences, they constitute the

the fact that "decentralization is not only about the distribution of competences, but also about the relations between higher and lower level bodies. Distribution of competences of the central body to the field bodies means that the process of deconcentration takes place. It may turn into the process of decentralization if lower level bodies have a degree of independence from higher-level bodies that allows them to be recognized as units of decentralized administration" [Ura, 2012, p. 95]. The mechanisms of social participation in municipal self-government function on the basis of the principle of deconcentration, because they do not have any independence vis à vis the municipality. They operate pro foro interno and are dependent on it in terms of organization and competences.

8 See the Act of 11 January 2018 on amending certain acts to increase the participation of citizens in the process of electing, operating and controlling certain public bodies (Journal of Laws, item 130).

Other auxiliary units of the municipality, created on the basis of article 5 AMSG are optional. These include named units 
implementation of the own task defined in article 7 par. 1 point 17 AMSG. They are created pursuant to the provisions of article 5 par. 1 of the Act of 15 March 2002 on the system of the Capital City of Warsaw ${ }^{10}$. Warsaw neighbourhoods were equipped by the legislator with the legislative body - the council and the board chaired by the mayor ${ }^{11}$, who is the executive body ${ }^{12}$.

Although the legislator set out a number of issues regarding the organization and functioning of the Warsaw neighbourhoods at the level of the Act, it left the Council of the Capital City of Warsaw significant competences in the scope of their operation. Thus the Council of the Capital City of Warsaw has the right to create, merge, divide and dissolve auxiliary units (after consultations with residents or on their initiative) and to establish neighbourhood statutes (defining the name of the neighbourhood, its boundaries, tasks and competences and the rules and mode of operation of its bodies). Whereas the executive body of the municipality is responsible for the execution of these resolutions and the preparation of changes in the budget, which enable the proper functioning of Warsaw neighbourhoods. "Neighbourhood statutes are adopted by the Council of the Capital City of Warsaw in the form of an annex to the resolution" [see Mazuryk, 2012]. It is possible to set up lower-level auxiliary units within Warsaw neighbourhoods, e.g. housing estates. Housing estates as lower-level units will operate on the basis of the provisions of the Act on municipal self-government and resolutions of Warsaw neighbourhood councils. The

(e.g. neighbourhoods, housing estates, villages) and others (e.g. hamlets, communities).

10 See the Act of 15 March 2002 on the system of the Capital City of Warsaw (consolidated text: Journal of Laws of 2015, item 1438, as amended) - hereinafter referred to as the AW.

1 Pursuant to article 10 AW the neighbourhood council elects the board composed of 3 to 5 members. In neighbourhoods with up to 100,000 residents, the neighbourhood board has a maximum of 3 members.

12 See article 6 AW. composition of housing estates in Warsaw, their organization and the rules of operation are defined by the neighbourhood council in the statutes. Their aim is to represent residents from a given area of the city, give opinions on projects, submit requests and take initiatives in all matters of local importance, indicated in the statutes. Housing estates cooperate with the bodies of Warsaw neighbourhoods in performing public tasks for the benefit of the residents of a given housing estate. In accordance with the provisions of $\S 48$ par. 1 of the Statutes of the Capital City of Warsaw "lower-level units in the Capital City of Warsaw are created by the neighbourhood council on its own initiative or at the request of at least 10 percent of persons who have an active electoral right to the City authorities, residing within the designed unit"13. Whereas organizational and technical conditions for these units are provided by the neighbourhood board.

The specificity of Warsaw neighbourhoods is based not only on the obligatory nature of their appointment, but also on the legislator's guarantee in the Act of a list of tasks reserved exclusively for neighbourhoods $^{14}$ and the financial resources ${ }^{15}$ allocated for their implementation. In the judgement of 24 November 2005 the Voivodeship Administrative Court in Warsaw indicated that "As tasks and competences referred to in article 11 par. 2 of the Act of 15 March 2002 on the system of the Capital City of Warsaw (Journal of Laws of 2002 No. 41, item 361, as amended) should be handed over to neigh-

\footnotetext{
13 See Statutes of the Capital City of Warsaw - resolution no. XII/223/2015 of the Council of the Capital City of Warsaw of 19 May 2015 on the announcement of the consolidated text regarding the adoption of the Statutes of the capital city of Warsaw, http://bip.warszawa.pl (access: 18.02.2018).

4 See article $11 \mathrm{AW}$.

15 In accordance with article 12 AW financial management of the neighbourhood is conducted on the basis of the neighbourhood annex to the budget resolution of the Capital City of Warsaw, determining the funds allocated to neighbourhoods for the implementation of their tasks.
} 
bourhoods of the capital city of Warsaw, which are its auxiliary units, the transfer of these tasks to the organizational units of the municipality in the form of budget units of the capital city of Warsaw violates, in a significant manner, the provision of article 11 par. 2 of this $\mathrm{Act}^{\prime 16}$. Guarantees regarding tasks and financial resources situate Warsaw neighbourhoods in a privileged position in relation to other auxiliary units of the municipality, which do not have this independence vis-àvis authorities, especially vis-à-vis the municipal council, being wholly dependent on the council in the scope of the tasks entrusted to it. In the judgement of 12 June 2007 the Supreme Administrative Court in Warsaw stated that: "The status of neighbourhoods of the Warsaw Municipality as its auxiliary units is different from the status of auxiliary units in other municipalities. They are auxiliary units with no legal personality, and therefore with no ,own' property"17.

According to article 7 par. 1 and par. 2 AW elections to neighbourhood councils are held together with elections to the council of the Capital City of Warsaw. Elections to the neighbourhood council are subject to the provisions of the Act of 5 January 2011 Electoral Code ${ }^{18}$ concerning the election of councillors to the municipal council in a municipality with more than 20,000 inhabitants, provided that electoral committees nominating candidates for the neighbourhood council are not entitled to free distribution of election programmes on public radio and public television due to such nomination ${ }^{19}$. Pursuant to article 7 par.

\footnotetext{
${ }^{16}$ See judgement of the Voivodeship Administrative Court in Warsaw of 24 November 2005 (II SA/Wa 760/05, LEX no. 213677).

17 See judgement of the Supreme Administrative Court in Warsaw of 12 June 2007 (II OSK 132/07, LEX no. 341083).

18 See Act of 5 January 2011 Electoral Code (Journal of Laws of 2017, item 15 and 1089 and of 2018 item 4), hereinafter referred to as EC.

19 Article 7 par. 2 as amended by article 4 of the Act of 11 January 2018 (Journal of Laws 2018.130) amending this Act on 31 January 2018.
}

3 AW "elections to neighbourhood councils are carried out by neighbourhood electoral commissions appointed in the mode and on the principles provided for municipal election commissions in municipalities with up to 20,000 inhabitants", and the division of neighbourhoods into constituencies is made by the Council of the Capital City of Warsaw. The legislator introduced a ban on simultaneous standing as a candidate to the district council and the legislative body of a territorial self-government unit. The provisions regarding municipal councillors apply accordingly to councillors of the Warsaw neighbourhood, and the number of councillors elected to the legislative district is determined on the basis of the provisions on the number of councillors elected to municipal councils ${ }^{20}$. In its judgement of the Supreme Administrative Court in Warsaw of 14 November 2017 stated that "The assessment of the scope and manner of ,accordingly' applying specific provisions to the councillors of Warsaw neighbourhoods must take into account the specific status of neighbourhoods, including the scope of tasks and competences assigned to them by law. Of course, this does not mean that the status of a neighbourhood councillor is not equal to the status of a councillor of the Capital City of Warsaw, this means only that the special status of Warsaw neighbourhoods affects the scope of applying accordingly the provisions of the Act of 2011 Electoral Code and AMSG to councillors of neighbourhood councils"21.

Satisfying the needs of local residents of neighbourhoods consists, among others in: adoption of resolutions by the council on matters falling within its competence, issuing administrative decisions (jurisdictional competences), issuing opinions on matters falling within the scope of the neighbourhood

\footnotetext{
20 See article 8 AW.

21 See judgement of the Supreme Administrative Court in Warsaw of 14 November 2017 (II OSK 2301/17, LEX no. 2426341).
} 
activity at the request of municipal bodies or on its own initiative, requesting municipal authorities to consider matters which are beyond the competences of a given neighbourhood. Competences of the neighbourhood also include conducting social consultations, presenting to municipal authorities projects of social and economic initiatives in the area of functioning of a given neighbourhood, cooperation with councillors from a given neighbourhood in organizing meetings with residents. An important issue in terms of meeting the needs of local residents in Warsaw neighbourhoods is also establishing cooperation with other neighbourhoods to implement joint initiatives, initiating social activities for the benefit of the local community by organizing events, social initiatives, organizing various forms of cultural life, sports and recreation in the neighbourhood important from the point of view of the community residing there and activities aimed at maintaining order, cleanliness and public safety. It is worth mentioning that inspiring various forms of social care and neighbourly assistance for people in a difficult life situation and organizing and coordinating projects aimed at improving the living conditions of the neighbourhood inhabitants are important activities of a given neighbourhood. This mechanism is a good example of an obligatory form of accomplishing own task in the form of satisfying the needs of local residents of neighbourhoods.

The civic initiative was introduced into the provisions of the Act on municipal selfgovernment based on the amendment of 11 January 2018 on amending certain acts to increase the participation of citizens in the process of electing, operating and controlling certain public bodies ${ }^{22}$. The legislator

22 Journal of Laws, item 130. In accordance with article 15 of the said amending Act the introduced changes apply to the term of office of territorial self-government units following the term during which the said Act entered into force. So far, the resolution initiative had no legal basis in the act. It was has decided on obligatory introduction of this instrument in the territorial self-government, indicating at the same time that in the municipality with up to 5,000 citizens civic resolution initiative may be submitted by at least 100 people, in the municipality with up to 20,000 - at least 200 , and in the municipality with more than 20,000 - at least 300 . By introducing a normative framework for the functioning of this instrument, the legislator enabled active inclusion of residents in the process of deciding on their own matters, of course within the scope of submission of a specific draft resolution for proceedings. Thus, satisfying collective needs of the community by supporting and disseminating the idea of self-government in the municipality has become possible on the basis of the Act. This instrument is quasi-obligatory, because the commencement of the entire procedure binds the municipal body, which is obliged to consider the submitted draft resolution, however after fulfilling certain formal conditions determination of which is de facto at the discretion of the municipal council. The legislative body of the territorial selfgovernment unit defines detailed rules for bringing in civic initiatives, rules for setting up committees for resolution initiatives, rules for promoting civic resolution initiatives and formal requirements for submitted drafts. The determination of the above-mentioned elements should take place by way of a resolution. These regulations should be considered the right direction for changes due to the creation of legal guarantees for the implementation of a civic resolution initiative in the municipality, but the decision to vote for a particular draft still belongs exclusively to the municipal council. A certain drawback of the proposed regulations is to leave key issues in the scope of functioning of this mechanism to the authority of the legislative

regulated on the basis of the regulations of the statutes of the municipality. 
body of the municipality. The executive body may participate in the verification of formal conditions of the submitted draft resolution.

Moreover, the legislator in article 41a par. 3 AMSG pointed out that "a draft resolution submitted as part of a civic resolution initiative becomes the subject of deliberations of the legislative body at the next session after submitting the draft, but not later than after 3 months from the day of submitting the draft." The use of a categorical term 'becomes' indicates the obligation to subject the draft to the council's deliberations. The clarification of this term makes it possible to proceed with the draft in question within a reasonable time-frame, and if it is not complied with, it may become the basis for lodging a complaint against the inaction of the legislative body in this respect [see Augustyniak, 2017a, p. 45]. Satisfying the collective needs of residents in supporting and disseminating the idea of self-government in the municipality using this form of participation of residents in managing the local community should include three elements:

- presenting draft resolutions in matters important to the local community, both on the city and neighbourhood level, falling within the scope of own tasks (e.g. building a playground in the municipality, co-financing the purchase of musical instruments for young people, organizing knowledge competitions about self-government, neighbourly assistance, supporting intergenerational dialogue in a given municipality through joint debates and projects of young people and seniors),

- initiating draft resolutions, the presentation of which belongs to the exclusive competence of the municipal bodies (e.g. draft budget),

- requesting initiation of joint initiatives of residents of various territorial self-government units in order to present a draft concerning a wider group of residents af- fected by the same problem or having the same social expectations.

The civic budget belongs to quasi-obligatory instruments serving the purpose of meeting the needs of local residents in terms of supporting and disseminating the selfgovernment idea in the municipality. It was introduced as a special form of public consultation to article 5a par. 3 AMSG pursuant to article 1 point $1 \mathrm{~b}$ ) of the Act of 11 January 2018 on amending certain acts to increase the participation of citizens in the process of electing, operating and controlling certain public bodies ${ }^{23}$. Thus it found his legal basis in the systemic self-government act. So far, it has been treated as an optional instrument, whose subjective and objective scope as well as formal conditions were regulated by the municipal council by means of a consultative resolution ${ }^{24}$ or by ordinances of the head of municipality and additionally by regulations in the municipal statutes. Currently, the quasi-obligatory character of this mechanism consists in its normative regulation in the act, with the proviso that the legislator still left important matters to the council's decision. As according to article 5a par. 7 the municipal council determines by way of a resolution the requirements to be met by the draft civic budget, in particular:

- formal requirements to be met by submitted drafts;

- the required number of signatures of residents supporting the draft;

- rules for the assessment of submitted drafts as to their compliance with the law, technical feasibility, formal requirements they meet and the procedure of appeal against the decision on refusal to allow the draft for voting;

- the rules governing the voting, determining the results and making them public,

\footnotetext{
23 Journal of Laws, item 130. This provision will apply to the next term of the bodies of territorial self-government units.

24 More on this topic in: [Marchaj, 2017].
} 
taking into account that the voting rules must ensure equality and directness of voting.

Moreover, the legislator introduced the obligation to create a civic budget only in municipalities that are cities with rights of the district, with the reservation that the amount of the civic budget is at least $0.5 \%$ of the municipality's expenditure contained in the last submitted report on budget implementation. This regulation guarantees normative co-management of the municipality by residents themselves, transferring on them some kind of responsibility for the legitimacy of matters being the subject of the civic budget.

Satisfying the needs of the local community consists, among others, in the fact that within the civic budget residents of the municipality in a direct vote decide annually on the part of the municipal budget expenditure, and the tasks selected by them are included in the budget resolution of the municipality (this applies for example to financing English lessons and computer learning for seniors, cultural and artistic projects for residents of a given neighbourhood, building a skatepark). A certain guarantee regarding the implementation of projects submitted within the civic budget is a prohibition on removing or changing to a significant degree the tasks selected within the civic budget by the municipal council in the course of work on the draft budget resolution. It should be emphasized that the tasks proposed by the residents must be included in the catalogue of tasks of the municipality of an optional nature. It is allowed to submit one or several tasks in accordance with the procedure laid down in this respect.

Residents of the municipality participate in the civic budget at the city and neighbourhood levels, because the legislator in article 5a par. 6 AMSG pointed out that "funds disbursed under the civic budget can be divided into pools covering the entire municipality and its parts in the form of auxiliary units or groups of auxiliary units".

\section{Satisfying collective needs of the community by supporting and disseminating the idea of self- government in the municipality - optional forms}

Promotion of the municipality and the idea of territorial self-government can be carried out through various forms of activities, including through organizing social and local events, conducting information and advisory activities and undertaking numerous civic initiatives. This applies in particular to the establishment of a municipal youth council and a municipal council of seniors. Both of these mechanisms satisfy the local needs of residents, enable them to engage in intergenerational dialogue, fostering active participation of young people and seniors in matters of the local community.

The municipal youth council is an optional instrument for the implementation of the own task of the municipality in the field of supporting and disseminating the self-government idea in the municipality in accordance with article 7 par. 1 point 17 AMSG $^{25}$. According to article 5b par. 1 AMSG the exclu-

\footnotetext{
25 See judgement of the Voivodeship Administrative Court in Gdańsk of 21 January 2016 (III SA/Gd 847/15, LEX no. 1984949), in which the Voivodeship Administrative Court indicated that article 7 par. 1 point 17 AMSG is a norm of a "task-oriented rather than competence-based nature and can not in itself be the basis of any imperative actions of the municipal body, in particular the basis for appointment by the executive body of the municipality of a social youth council (...) no provision prohibits the establishment of an advisory body at the municipal executive body, i.e. the social youth council, the Court would like to point out that in public law relations (and these include the activities and functioning of self-government bodies) the rule "what is not prohibited is allowed" does not apply, but the principle that only what the law explicitly provides is allowed, because according to article 7 of the Constitution of the Republic of Poland, public authorities operate on the basis and within the limits of the law, and therefore the independence of the municipal bodies exists only within the limits of the established law."
} 
sive competence of the municipal council is the creation of a youth municipal council, by way of a resolution, at the request of the communities concerned. The competences of the municipal council include appointing a youth council, giving it statutes and defining in it the mode of election of its members and the rules of operation of this body ${ }^{26}$. Therefore, the electoral law for the youth municipal council can not be regulated by an order of the executive body of the municipality, despite authorizing it in the resolution of the municipal council. The resolution of the municipal council on this matter is also flawed, because the subdelegation of exclusive competence of the municipal council is prohibited. This is also confirmed by administrative case law. In the supervisory decision of 22 June 2016, the Governor of Wielkopolska indicated that "Since the legislator imposed on the municipal council the obligation to regulate the mode of electing members of the municipal youth council in the statutes, it is unacceptable to circumvent this requirement by delegating the above-mentioned competences to the Mayor and thereby regulating the electoral law in a separate document, not constituting a local law act"27. Modest statutory regulations regarding the functioning of the municipal youth council prove that the legislator left a whole range of organizational and legal issues to be regulated by the municipal council in the statutes of these councils.

\footnotetext{
${ }^{26}$ In the decision of the Governor of Lower Silesia from 30 June 2015 (NK-N.4131.43.4.2015.JW1, Dolno.2015/3042) it was pointed out that "the participation of members (councillors) of the youth municipal council in meetings of the municipal council is not a rule of operation of the youth municipal council." It is the activity of individual "youth councillors detached from the rules of operation of the youth council itself. Therefore, the right to participate in the meetings of the municipal council can not be an element of the statutes of the youth municipal council."

27 See supervisory decision of the Governor of Wielkopolska of 22.06.2016 (KN-I.4131.1.189.2016.15, Journal of Laws Wielkopolskie Voivodeship, item 4508).
}

A member of a youth council may be a resident of a given municipality who is under 18 years of age (a junior high school or high school student, rarely elementary school pupils). However, these issues may be differently regulated in the statutes, which also means the possibility of admitting students to the group of entities participating in this body [Augustyniak, 2017b, p. 406]. The municipal youth council, being a body composed of young people, with little professional and social experience, requires support from the municipal bodies and cooperation in action. The municipal authorities should also provide the municipal youth council with financial support in the area of its tasks and undertakings. M. Mączyński indicates that "such cofinancing may have its source in the expenses of the municipal council, but it may also come from other entities willing to financially support the activities of the municipal youth council (e.g. foundations, youth organizations, associations)" [Mączyński, 2013, p. 141 et seq.]. Young people who participate in the consultation process should be informed about the activities undertaken by the municipal authorities to ensure proper mutual relations between the council and representatives of the authorities.

The municipal youth council is created as a space for exchange of positions and experience, as a consultative forum on matters concerning youth in the municipality and other matters referred to them by the municipal authorities for the opinion. It is also a meeting place for young people learning self-government participation. It is an opportunity to express one's own ideas. Being an educational and self-government platform, it enables the presentation of requests and projects to the municipal authorities in matters directly related to them. The youth council is also a form of cooperation with the municipal council and the head of municipality (mayor, president of the city) on undertakings concerning the entire local community in the 
field of youth self-government. Thus, it fulfils the task of article 7 par. 1 point 17 AMSG.

Municipal council of seniors is a mechanism of social participation in the local community. It belongs to optional instruments for the implementation of the municipality's own task in the area of supporting and disseminating the idea of self-government. Municipal councils of seniors and senior councils of an auxiliary unit may function within the municipal structure. The latter may be established pursuant to article $5 c$ par. 6 AMSG within auxiliary units of the municipality. The municipal council of seniors is consultative and initiative-oriented. The purpose of its establishment is to create conditions for stimulating civic activity of older people in the local community, which promotes intergenerational solidarity and the implementation of programmes to stimulate civic activity. This mechanism operates only in municipalities, because there are no legal grounds to establish it at the district or voivodeship level. In the Act of 8 March 1990 on municipal self-government, the legislator defined the framework for the functioning of this participatory mechanism, indicating that the municipal council of seniors consists of representatives of elderly people living on the territory of a given unit, representatives of entities acting for the elderly, in particular representatives of non-governmental organizations and entities running Third Age Universities. In the judgement of 27 October 2017, the Supreme Administrative Court in Warsaw ruled that "determining the age entitling to participate in the senior council is extremely important, since according to article 5c par. 4 AMSG its members are to be representatives of the elderly. Therefore, fulfilment of the instruction in article 5c AMSG requires from the municipal council to give a specific meaning to the term 'senior', because the lack of this regulation would in fact prevent the functioning of the senior council and violate the right of the territorial self- government unit to set up a municipal council of seniors, give its statutes and determine the mode of election of its members and rules of operation." ${ }^{28}$. Whereas issues regarding the rules of election are governed by the statutes of a given senior council, adopted by a resolution of the municipal council, by a simple majority of votes, in the presence of at least half of the statutory composition of the council, in an open vote. The legislator did not specify the age limit on the basis of which natural persons could be qualified to the elderly, which raises legitimate legal doubts, which is why provisions of the statutes quite freely establish this limit. In the judgement of 14 September 2015, the Voivodeship Administrative Court in Gliwice ruled that it is not allowed to determine in the statutes of the municipal council of seniors that its member will be a representative of the city council or representative of the city president, because the catalogue of members of the council has been indicated by the legislator, therefore the modification in this scope is not admissible ${ }^{29}$.

The catalogue of tasks of this form of participation, falling within the scope of meeting the needs of local residents under article 7 par. 1 point 17 AMSG, includes in particular:

- co-creating and developing appropriate ways of responding to the problems of the municipality - to this end, members of the municipal council of seniors are allowed to meet representatives of the municipal authorities and officials as well as experts appointed by the municipality as regards specific matters within its competence;

- presenting solutions proposed by seniors in matters related to infrastructure improvement, elimination of architectural

\footnotetext{
28 See grounds for the judgement of the Supreme Administrative Court in Warsaw of 27 October 2017 (II OSK 349/16, LEX no. 2436163).

29 See judgement of the Voivodeship Administrative Court in Gliwice of 14 September 2015 (IV SA/GI 14/15, LEX no. 1823129).
} 
barriers and implementation of social assistance activities and programmes targeted at elderly people who are in a difficult life situation;

- participating in the work of various commissions, teams and thematic groups, selected as part of the senior council, devoted to specific issues dealt with by the municipality and presenting specific ideas and solutions to problems important for the elderly, in the form of resolutions, opinions and requests and desiderata.

It should be emphasized that the implementation of programmes to stimulate civic activity, which is one of the forms of fulfilling the needs of local residents, also takes place through the activity of non-governmental organizations $s^{30}$, including associations and foundations ${ }^{31}$. The legislator allows a wide range of social economy entities ${ }^{32}$ to co-manage the affairs of the self-government community. Without cooperation with the third sector, meeting social needs in the light of article 7 par. 1 point 17 of the Act on municipal self-government would not be fully possible.

\section{Conclusions and proposals}

As D. Wacinkiewicz points out, "one of the dimensions of the principle of decentralization, strongly related to the principle of subsidiarity in the organizational and functional aspect, is the requirement for the legislator to seek optimal structural solutions, enabling territorial self-government units to perform public tasks in the best possible way. The key criterion for assessing the adopted organizational and functional concept becomes

\footnotetext{
30 About non-governmental organizations and their forms of activity, see more: [Małecka-Łyszczek, 2017, p. 234 et seq.]. See on the subject of cooperation between non-governmental organizations and French territorial communities: [Zacharko, 2017, p. 777].

31 More on their legal status, see: [Blicharz, 1996, p. 7 et seq.]. See also: [Cioch, 2011].

32 See on this subject: [Moskaluk-Łagiewczyk, 2012, p. 221 et seq.]. See also: [lzdebski, 2007, nr 1, p. 49 et seq.].
}

the ability of local corporations to meet the needs of self-government communities constituting the essence of self-government own tasks" [Wacinkiewicz, 2016, p. 323].

Obligatory, quasi-obligatory and optional mechanisms for the implementation of the own task in the form of satisfying the needs of local residents in the self-government community in the light of article 7 par. 1 point 17 of the Act on municipal self-government are a challenge for the legislator and the local resolution-passing body.

The Warsaw neighbourhoods are an expression of the deconcentration of public tasks transferred by the municipality. They are not a form of decentralization, because they do not have independence provided for by law towards municipalities, although a certain catalogue of tasks and resources for their implementation is guaranteed under the Act. The public and legal status of the Warsaw neighbourhoods is determined by the ability to handle public affairs, including own tasks. The postulate is for the legislator to equip the Warsaw neighbourhoods with a normative, defined range of tasks and competences under the Act, to support and disseminate the self-government idea in the municipality, which will enable participants in this participatory form to seek their rights before the administrative court. This will strengthen the forms of implementation of tasks in the field of meeting the needs of local residents of the municipality.

Quasi-obligatory forms in the scope of supporting and dissemination of the selfgovernment idea include the civic initiative and the civic budget whose legal norms are now set by the provisions of the Act. Both of these mechanisms allow for the active participation of residents both in submitting a draft resolution to the municipal council deliberations in all matters concerning the municipality's own tasks (not falling within the exclusive competence of the municipal authorities), and in shaping financial policy, 
in the form of the possibility of submitting a specific task to funding from the municipal budget. These instruments bring the citizen closer to the municipal bodies, influencing the shape of relations between authorities. They are a manifestation of the implementation of the principle of subsidiarity, although their quasi-obligatory nature still manifests the distrustful attitude of the legislator to the forms of direct democracy which may affect the real management of local community affairs.

The municipal youth council and the municipal council of seniors are a manifestation of the implementation of support and dissemination of the self-government idea among young people and elderly people, among others by issuing opinions on legal acts issued by municipal bodies concerning young people and seniors, as well as submitting requests in matters important to them to authorities, disseminating information about the activities of these mechanisms of social participation among the communities, undertaking activities aimed at disseminating information and education policy concerning

\section{References}

Augustyniak M. (2017a). „O pozorności praw obywatelskich w przestrzeni publicznej na podstawie wybranych mechanizmów partycypacji społecznej w samorządzie terytorialnym" [On the ostensibility of civil rights in public space on the basis of selected mechanisms of social participation in territorial self-government], Przegląd Prawa Publicznego, nr 3.

Augustyniak M. (2017b). Partycypacja społeczna w samorzadzie terytorialnym w Polsce i we Francji. Studium administracyjnoprawne na tle porównawczym [Social participation in territorial self-government in Poland and France. Administrative and legal study on the comparative background]. Warszawa: Wolters Kluwer.

Blicharz J. (1996). „Pozycja prawna stowarzyszeń. Studium prawnoadministarcyjne" [Position of the law on associations. Legal and administrative study], Acta Universitatis Wratislaviensis. Prawo, nr 255.

Cioch H. (2011). Prawo fundacyjne [Law on foundations]. Warszawa: Wolters Kluwer Polska. the municipal self-government. These activities also include creating a framework for cooperation with other environments and bodies, for example by creating intergenerational dialogue. Both of these mechanisms constitute the added value of the idea of selfgovernment and the principle of subsidiarity.

Obligatory, quasi-obligatory and optional mechanisms are a good example of instruments for the implementation of the own task in the form of satisfying the needs of local residents in the local community. However, we should seek to broaden the catalogue of forms of support and dissemination of the self-government idea, so that the relations between the municipal bodies enable full implementation of the principle of subsidiarity and social participation in this basic unit of the territorial division of the state, which is the municipality. The greater the participation of residents in the management of the local community, the more efficient execution of its own tasks and the more complete legitimisation of the activities of the authorities.

Dolnicki B. (2000). Zadania samorządu terytorialnego [Tasks of territorial self-government], in: R. Mikosz (ed.), Rozprawy prawnicze. Księga pamiątkowa dla uczczenia pracy naukowej Profesora Antoniego Agopszowicza [Legal treatises. A memorial book to commemorate academic work of Professor Antoni Agopszowicz]. Katowice: Wydawnictwo Uniwersytetu Śląskiego.

Duniewska Z., Jaworska-Dębska B., Michalska-Badziak R., Olejniczak-Szałowska E., Stahl M. (2004). Prawo administracyjne. Pojęcia, instytucje, zasady w teorii i orzecznictwie [Administrative law. Concepts, institutions, principles in theory and case law]. Warszawa: Difin.

Izdebski H. (2007). „Czym jest ekonomia społeczna” [What is social economy], Ekonomia Społeczna, nr 1.

Małecka-Łyszczek M. (2017). Współpraca administracji publicznej z podmiotami ekonomii społecznej. Aspekty administracyjnoprawne [Cooperation between public administration and social economy entities. Administrative and legal aspects]. Warszawa: Wolters Kluwer Polska.

Mączyński M. (2013). "Komentarz do art. 5b” [Commentary to art. 5b], in: P. Chmielnicki (ed.), Ustawa 
o samorzadzie gminnym. Komentarz [Act on municipal self-government. Commentary]. Warszawa: LexisNexis.

Marchaj R. (2017). „Charakter prawny uchwały w sprawie przeprowadzenia budżetu obywatelskiego" [Legal nature of the resolution on the right to carry out a civic budget], Samorzad Terytorialny, nr 11, p. 5-14.

Mazuryk M. (2012). „Komentarz do art. 5” [Commentary to art. 5], in: M. Karpiuk, M. Mazuryk (ed.), Ustrój miasta stołecznego Warszawy. Komentarz [System of the Capital City of Warsaw. Commentary]. Warszawa: LEX/el.

Moll T. (2016). "Komentarz do art. 7" [Commentary to art. 7], in: B. Dolnicki (ed.), Ustawa o samorządzie gminnym. Komentarz [Act on the municipal self-government. Commentary]. Warszawa: Dom Wydawniczy ABC Grupa Wolters Kluwer.

Moskaluk-Łagiewczyk K. (2012). Podmioty ekonomii społecznej w działalności sektora publicznego [Entities of social economy in activities of the public sector], in: J. Blicharz (ed.), Prawne procesy prywatyzacji [Legal privatisation processes]. Wrocław: Prawnicza i Ekonomiczna Biblioteka Cyfrowa.

Stasikowski R. (2005). Gwarancje samorząności gminnej w systemie prawnym Republiki Federalnej Niemiec i Rzeczypospolitej Polskiej [Guarantees of munici- pal self-government in the legal system of the Federal Republic of Germany and the Republic of Poland]. Bydgoszcz-Katowice: Oficyna Wydawnicza Branta.

Szydło M. (2008). Ustawa o gospodarce komunalnej [Act on municipal management]. Warszawa: Wolters Kluwer Polska.

Ura E. (2012). Prawo administracyjne [Administrative law]. Warszawa: LexisNexis Polska Sp. z o.o.

Wacinkiewicz D. (2016). Zaspokajanie potrzeb wspólnot samorzadowych. Studium administracyjnoprawne [Satisfying the needs of self-government communities. Administrative law study]. Warsaw: C.H.Beck.

Wiktorowska A. (2013). "Samorząd terytorialny" [Local self-government], in: M. Wierzbowski (ed.), Prawo administracyjne [Administrative law]. Warszawa: Wolters Kluwer S.A.

Zacharko L. (2017). Innowacyjne rozwiązania w zakresie realizacji zadań publicznych gminy w Polsce i we Francji - modele kontraktowania usług publicznych [Innovative solutions in the implementation of public tasks of the municipality in Poland and France - models for contracting public services], in: B. Dolnicki (ed.), Sposoby realizacji zadań publicznych [Ways of implementing public tasks]. Warszawa: Wolters Kluwer SA.

\section{O zaspokajaniu zbiorowych potrzeb wspólnoty lokalnej - wybrane zagadnienia}

Streszczenie: Przedmiotem niniejszego artykułu jest analiza jednego z zadań własnych, które ma na celu zaspokajanie potrzeb wspólnoty lokalnej poprzez wspieranie i upowszechnianie idei samorządowej, w tym tworzenie warunków do działania i rozwoju jednostek pomocniczych i wdrażania programów pobudzania aktywności obywatelskiej. Przedmiotowa problematyka została przedstawiona w oparciu o obligatoryjne, quasi-obligatoryjne i fakultatywne formy zaspokajania zbiorowych potrzeb wspólnoty w świetle art. 7 ust. 1 pkt 17 ustawy o samorządzie gminnym, wraz ze wskazaniem roli i znaczenia organów gminy w strukturze organizacyjnej i funkcjonalnej zaprezentowanych mechanizmów, za pomocą których realizowane jest to zadanie własne gminy. Omówienie przedmiotowego zadania jest istotne z uwagi na to, że stanowi formę realizacji zasady subsydiarności i dekoncentracji we wspólnocie samorządowej.

Słowa kluczowe: partycypacja społeczna, obligatoryjne i fakultatywne formy zaspokajania zbiorowych potrzeb wspólnoty lokalnej poprzez wspieranie i upowszechnianie idei samorządowej, subsydiarność i dekoncentracja.

\section{Prawa autorskie i licencja / Copyright and License}

Artykuł opublikowano na licencji Creative Commons Uznanie autorstwa - Użycie niekomercyjne - Bez utworów zależnych 3.0 Polska http://creativecommons.org/licenses/by-nc-nd/3.0/pl/

This article is published under the terms of the Creative Commons Attribution - NonCommercial - NoDerivs (CC BY-NGND 3.0) License http://creativecommons.org/licenses/by-nc-nd/3.0/ 